9. Novikova, E. (2011). Reprezentatsiya improvizatsii v dzhazovoi muzyke [Representation of improvisation in jazz music]. Tsennosti i smysly, no. 6(15), pp. 77-84.

10. Petrov, A. (2012). Marginal'nost' kak proyavlenie svobody myshleniya [Marginality as a manifestation of freedom of thought]. Vestnik Omskogo universiteta, no.3, pp. 26-29.

11. Peshev, D. (2015). Klassifikatsiya afroamerikanskikh muzykal'nykh zhanrov severnoi ameriki: istoriya voprosa [Classification of African American music genres in North America: background]. Sovremennye naukoemkie tekhnologii, no.12(5), pp. 924-928.

12. Priestley, B. (2007) Chasin' the Bird: The Life and Legacy of Charlie Parker. USA: Oxford University Press.

13. Voelpel, M. (2001). Charlie Parker for Guitar. USA: Hal Leonard.

(C) Журба В. В., 2018

Стаття надійшла до редакиії 25.09.2018

УДК 78.036.9

Журба Яніна Олексї̈вна

аспірантка,

Київський національний університет

культури і мистеитв,

вул. С. Коновальия, 36, Київ, Україна, 01133, https://orcid.org/0000-0002-8466-4888

zzjazz.com@gmail.com

\title{
РОЛЬ БЛЮЗУ В ДЖАЗОВІЙ МУЗИЦІ
}

Мета роботи. Визначити роль блюзу в джазовій музиці. Методологічною основою дослідження $\epsilon$ метод системного аналізу. Наукова новизна. У результаті проведеного дослідження, вперше в українському музикознавстві визначений вплив блюзу на джазову музику в аспекті його характерних рис як музичного жанру, музичного стилю та музичної форми. Висновки. Блюз має велике значення для процесу становлення джазової музики, оскільки його особливості як музичного жанру, музичного стилю і музичної форми отримали широке відображення в рамках виділеного сегменту неакадемічної музики XX ст.

Ключові слова: блюз; джаз; музичний жанр; музичний стиль; музична форма.

Журба Янина Алексеевна, аспирантка, Киевский национальный университет культуры и искусств, ул. Е. Коновальиа,36, Киев, Украина

Роль блюза в джазовой музыке

Цель работы. Определить роль блюза в джазовой музыке. Методологической основой исследования является метод системного анализа. Научная новизна. В результате проведенного исследования, впервые в украинском искусствоведении определено влияние блюза на джазовую музыку в аспекте его характерных черт как музыкального жанра, музыкального стиля и музыкальной формы. Выводы. Блюз имеет большое значение для процесса становления джазовой музыки, поскольку его особенности как музыкального жанра, музыкального стиля и музыкальной формы получили широкое отражение в рамках выделенного сегмента неакадемической музыки XX ст.

Ключевые слова: блюз; джаз; музыкальный жанр; музыкальный стиль; музыкальная форма.

Zhurba Yanina, Postgraduate, Kyiv National University of Culture and Arts, 36, Y. Konovaltsia St, Kyiv, Ukraine

The role of blues in jazz music 
The purpose of the article is to define the role of blues in jazz music. The research methodology consisted in the method of system analysis. The scientific novelty of the work. As a result of the research, the influence of blues on jazz music in terms of its characteristic features as a musical genre, musical style and musical form was defined for the first time in Ukrainian musicology. Conclusions. Blues played a great role in the formation of jazz music since its characteristics as a musical genre, musical style and musical form were widely reflected in the selected segment of non-academic music of the $20^{\text {th }}$ century.

Key words: blues; jazz; musical genre; musical style; musical form.

Вступ. Блюз $€$ одним 3 основоположних явищ неакадемічної музики $\mathrm{XX}$ ст. Феноменальність зазначеного музичного явища полягає в складному та об'ємному комплексі його характерних особливостей, які можна класифікувати як елементи музичного жанру, музичного стилю та музичної форми. Необхідно зазначити, що визначеним характеристикам блюзу притаманна неперевершена яскравість та автентичність, що сприяла процесу впливу блюзу на велику кількість музичних стилів та напрямків неакадемічної музики XX ст. А головне в тому, що певні з його характерних особливостей стали їх невід'ємною частиною. Важливим також є той факт, що визначений процес прояву блюзових ознак відбувався в аспекті всього спектру його характерних особливостей. Не є винятком і джазова музика, яка $\epsilon$ потужним пластом неакадемічної музики XX ст.: блюз відіграє велику роль у процесі їі розвитку та становлення.

Актуальність теми дослідження. Про спорідненість блюзу та джазу свідчать твердження певної кількості дослідників неакадемічної музики ХX ст. Про стратегічне значення блюзу для джазової музики зауважують Й. Берендт та Г. Хьюсмен в роботі «Тhe Jazz Book. From Ragtime To The 21st Century: «Коли перші маршові оркестри почали грати в Новому Орлеані, існувала різниця між започаткованим ними “джазом" та блюзом. Але незабаром сільський блюз почав вливатися в основну течію джазу, і з того часу джаз і блюз ... переплелися ... Навіть сучасний ... джазовий музикант сьогодні $\epsilon$ в боргу перед блюзом; насправді блюзова свідомість вища в сьогоднішньому джаз, ніж у багатьох попередніх стилях» (Berendt, Huesman, 2009, с. 11). Походження стильових рис джазу, а саме гармонії таких стилів та напрямків, як boogie-woogie, новоорлеанський джаз, чикагський джаз, свінг, музичний стиль bebop підмічає Ю. Чугунов в роботі «Гармония в джазе» (Чугунов, 1988, c. 98-100). А. Шевченко в статті «Специфіка вокально-джазової культури виконавців» пише про спорідненість блюзу і джазу в аспекті виконавських прийомів: «Джазова манера відрізняється особливими способами інтонування - блюзове інтонування» (Шевченко, 2017, с. 176). Крім того, автор вказує наступне: «Блюзове інтонування використовується не тільки під час виконання блюзів, а й під час виконання джазових стандартів (Шевченко, 2017, с. 176-177). Про спорідненість джазової музики та блюзу як жанру пише С. Амірханова в монографії «Джаз как искусство самовыражения»: «...домінуючим жанром, що визначив як мелодико-інтонаційний лад джазу, так i його конструктивну основу, став блюз» (Амирханова, 2009, с. 98). Виокремлює стилістичне походження джазової музики від блюзу в ракурсі музичного стилю і О. Назін в статті «Особенности взаимодействия музыкального языка джаза и рок-музыки в XX - начале XXI веков»: «На початкових етапах становлення джазу мелодійне мислення було досить простим і визначалося правилами, що склалися поруч в рамках блюзу, регтайму і спірічуелу» (Назин, 2014, с. 133). Про фундаментальне значення блюзу для джазової музики в аспекті виконавської техніки зазначає О. Леурда в статті «Технические и исторические аспекты мелизмов в массовой музыке XX века»: «Треба сказати, що блюз з його музично-виразною системою став фундаментом для подальших музичних поколінь естрадно-джазової музики» (Леурда, 2017, с. 113). Крім того, автор зауважує: «Мелізми використовували в різні епохи становлення вокального мистецтва, але найбільш інтенсивний їх розвиток відбувся в другій половині XX ст. Вважаємо, що збагачення даної техніки новим змістом було пов'язане 3 впливом різних видів афроамериканського фольклору. Інтонаціями скорботи, тривоги і страждань просякнуті 
мелізматичні поспівки, що ріднить їх з блюзовою музикою» (Леурда, 2017, с. 114). Однак бракує наукових досліджень, що були б спрямовані на систематизоване виявлення ролі блюзу в джазовій музиці.

Мета дослідження - з'ясувати роль блюзу в джазовій музиці.

Виклад основного матеріалу. Блюз та джаз ріднить велика кількість спільних рис: походження з середовища афро-американських спільнот, засоби розповсюдження, що як наслідок, призвело до трансформації їх у національну та навіть міжнародну форми мистецтва тощо. Крім того, необхідно визначити, що блюз відіграє основоположну роль у межах творчості певної кількості відомих джазових музикантів. Зокрема Д. Колтрейна, який в ранньому періоді своєї кар'єри часто грав у бендах, які виконували блюз, що, безумовно, певним чином відобразилося на формуванні його виконавського стилю, і в складі кожного його альбому $є$ принаймні один твір, що написаний або виконаний у блюзовому стилі; Д. Бенсон та У. Монтгомері, словник музичної мови яких безперечно був багатий на блюзові інтонації; творчість Ч. Мінгуса зазнала певного впливу блюзу в 50-х pp. ХХ ст.; Л. Армстронг, який використовував блюз як основу для багатьох своїх найважливіших композицій, серед яких «Dippermouth Blues», «Gutbucket Blues», «Lonesome Blues», «Muggles», «Potato Head Blues», «St James Infirmary», «West End Blues»; Ч. Паркер, який $\epsilon$ автором понад 170 блюзових творів; К. Бейсі, який вважав, що джаз - це свінгований блюз; С. Коулман та К. Вілсон зберегли творчу сфокусованість на блюзі, використавши його характерні елементи для концепції свого індивідуального виконавського стилю; Д. Кролл та Д. Редман ще й сьогодні виконують блюз практично в його незмінному вигляді та ін. Але вважаючи необхідним конкретизувати ступінь важливості ролі блюзу в межах джазової музики перейдемо до уточнення спільних характеристик зазначених явищ неакадемічної музики XX ст.

Досліджуючи питання наявності характерних ознак блюзу в джазовій музиці, насамперед необхідно зазначити один фактор. Він відображений у характерних ознаках музичного стилю, що панував в 40-х рр. XX ст. та визначається в історії джазової музики як bebop. Як відомо, зазначений музичний стиль виник як своєрідний знак протесту до пануючого в ті часи музичного строю. Передусім, блюз є вираженням людських страждань, що відбувалися в результаті конфлікту різних культур та утиску прав людини. Влучно характеризує блюз Д. Коллієр в роботі «Луи Армстронг. Американский гений» пишучи, що «...блюз - це крик відчаю, що вирвався з горла людей які були стерті в прах» (Коллиер, 1987, c. 122). Тобто імпульсом для творчості і в межах блюзу, і в межах музичного стилю bebop було несприйняття подій, що відбуваються в оточуючому середовищі. Безперечно, очевидним $\epsilon$ те, що реакція на таке несприйняття в них була різна: в блюзі іiі можна визначити як своєрідну смиренність та усвідомлення того факту, що нічого не можна змінити, в музичному стилі bebop головним ідейним стрижнем є фактор непокори та боротьби. Подібне спостереження надає нам право визначити належність блюзу до категорії субкультури, а музичний стиль bebop - контркультури. Але головний виток і в першому, і в другому випадку є спільним та його можна визначити як маргінальність. Причому, в даному випадку зазначене явище маргінальності мало основоположне значення, оскільки музичний стиль bebop 3 причини кристалізації в його рамках новітньої концепції трактування джазового виконавства, знаменував початок нової ери в контексті історії джазової музики. Мова йде, насамперед, про зміщення джазової музичної культури в новий простір, що визначається як елітарна культура. Також, на користь вищевказаного визначення можна віднести той факт, що культурні феномени, що мають маргінальні ознаки є головним фактором розвитку культури та їх «функція ... складається в демонстрації різноманітності» (Бобер, 2010, с.140). Проектуючи зазначену ознаку на характеристики музичного стилю bebop, ми можемо зазначити, що складові його музичної мови, концепція викладання музичного матеріалу, манера сценічної поведінки артистів тощо сприймалася прихильниками джазової музики як дещо дійсно нове та незвичне, що, передусім, надає нам право вказати на прояви рис маргінальності в межах зазначеного явища. Крім того, в даному 
випадку буде доречним застосування до визначеного явища музичної культури терміну, що має більш масштабне значення, а саме: простір культурної маргінальності. Як визначає Ж. Бобер в статті «Культурная маргинальность и ее место в развитии культуры», наведене поняття - «це простір, з одного боку, вростання інновації в традицію через розширення меж і перспектив традиції, з іншого - заперечення традиції через руйнування ії стандартів і норм» (Бобер, 2010, с. 139). Як відомо, саме в межах музичного стилю bebop відбулися трансформаційні процеси, що призвели до переходу від ери традиційного джазу до ери Modern Jazz, тому вказаний термін якнайкраще відображує сутність зазначеного явища неакадемічної музики XX ст. Зауважимо, що зазначену характеристику ми можемо визначити як похідну саме від блюзу, оскільки з часів блюзу до появи стилю bebop в межах неакадемічної музики XX ст. не існувало музичних явищ з виокремленою ознакою.

Звернімося до питання жанрової спільності джазу та блюзу. Однією з найголовніших рис блюзу як жанру є поєднання функції автора та виконавця в одній особі. Визначене явище веде до того, що в блюзовій музиці імпровізаційність виділяється як головний принцип створення музичного матеріалу. Подібний процес відбувається і в джазовій музиці, тому зазначений аспект можна виокремити як споріднену рису джазу та блюзу як музичного жанру. Таке визначення має важливе значення, оскільки в контексті джазової музики імпровізація $\epsilon$ не тільки засобом викладення музичного матеріалу, а $\mathrm{i} \epsilon$ носієм його стратегічних ідей. Як зазначає С. Амірханова в дослідженні «Джаз как искусство самовыражения»: «Музична виконавська імпровізація стала найважливішим виразом свободи в джазі, оскільки містила в собі можливість протиставити константності структурно композиційному принципу “композиторської музики”» (Амирханова, 2014, с. 106). Безперечно, можна зауважити, що імпровізаційність, як головний принцип викладення музичного матеріалу притаманна не лише блюзу, тому на джазову музику визначена тенденція могла вплинути від їі іншого витоку - регтайму. Але необхідно зазначити, що імпровізаційна основа в блюзі виражена в значно більшій мірі. На підтвердження цього маємо вислів В. Сирова, який викладений в його монографії «Стилевые метаморфозы рока или путь к третьей музыке»: «3 усіх жанрів афро-американського фольклору блюз $\epsilon$ найбільш відкритим і динамічним. Особливо яскраво це видно під час порівнянні блюзу і спірічуел, блюзу і регтайму, блюзу і кантрі» (Сыров, 1997, с. 100). Незаперечним фактом $\epsilon$ те, що в процесі розвитку регтайму, його вищезазначена імпровізаційна основа, була втрачена та регтайм перейшов до жанрів суто композиторської музики ${ }^{9}$. У той час, як в блюзі імпровізаційність так і залишилася головним принципом музичного «мовлення». Необхідно зазначити, що визначений аспект отримав найбільший відгук в джазовій музиці у 40-х рp. $\mathrm{XX}$ ст. в рамках музичного стилю bebop. Каталізатором цього явища було повне зникнення свободи у створенні музики в часи панування свінгу, а саме в 30-х рр. XX ст. Оркестрові аранжування, в яких було виокремлено лише декілька тактів для імпровізації $\epsilon$ підтвердженням цього факту. Тому є цілком невипадковим, що музиканти нового стилю, шукаючи «музичної свободи», знайшли джерело свого натхнення в самих витоках джазової музики, а саме в блюзі. Визначений вплив від блюзу в межах зазначеного явища мав досить масштабний характер, оскільки серед характерних ознак музичного стилю bebop є яскраво вираженими риси блюзу не тільки як музичного жанру, а й як музичного стилю.

Продовжуючи розгляд питання впливу блюзу на джазову музику як музичного жанру, необхідно визначити аспект сольної імпровізації, що, як відомо, є характерною жанровою ознакою блюзової музики. Вплив у вищезазначеному напрямку також найширше виявляється в музичному стилі bebop, в рамках якого в джазовій музиці відбувається встановлення сольної імпровізації, як головної концепції організації музичного матеріалу. Прослідковуючи історію розвитку джазової музики, ми можемо зауважити, що з самого початку ії існування, а саме 3 ново-орлеанського періоду для джазу був характерним прийом колективної імпровізації. Крім того, головною концепцією викладення музичного матеріалу в межах

\footnotetext{
${ }^{9}$ Під композиторською музикою мається на увазі відсутність імпровізаційності в процесі викладення музичного матеріалу.
} 
джазової музики також можна визначити групове виконання. К. Коровіна в авторефераті дисертаційного дослідження «Происхождение американского блюза как проблема культурологического понимания» зауважує, що подібний висновок можна зробити, виходячи 3 основного переліку інструментів, що «є базовим у процесі музикування» в джазі та блюзі (Коровина, 2005, с. 24). Винятки мають лише сольні фортепіанні джазові стилі, такі як bluespiano, boogie-woogie та ін. У той час, як в межах музичного стилю bebop виділення індивідуальності як центру музичних подій та виведення на перший план її світосприйняття, емоцій та творчих думок стає провідною лінією творчого процесу. Необхідно також визначити, що подібна тенденція, яка бере початок саме від блюзу, надалі набула концептуального значення для джазової музики та отримала найяскравіше відображення в музичному напрямку сучасного джазу free jazz.

Об'єктивним є той факт, що відображення визначених ознак блюзу має лише частковий прояв в джазовій музиці, яка за своїми жанровими ознаками є мистецтвом розважального характеру. Але необхідно також усвідомлювати і той факт, що в процесі розвитку визначеного музичного напрямку, в його контексті має місце музичний стиль, який має характеристики, що визначаються як похідні від блюзу, як музичного жанру. Крім того, значимість виділеного музичного стилю в контексті становлення та розвитку джазової музики не викликає сумнівів, тому важливе правильне розуміння його витоків.

Переходячи до розгляду питання стилістичної спорідненості блюзової та джазової музики, необхідно звернутися до принципів мелодичної організації в джазі. На подібну спорідненість мелодики блюзу та джазу вказує в монографії «Джаз как искусство самовыражения» i C. Амірханова: «Саме на ...виробленому в межах цього жанру мелодичному звукоряді (“блюзовому ладі”) заснована величезна кількість джазових композицій» (Амирханова, 2014, с. 98). Пояснюючи подібне твердження, ми можемо зазначити, що в цьому випадку мелодики джазу спирається на звукоряд блюзової діатоніки та, як наслідок, на пентатонічну основу міжступеневого тяжіння, яке притаманне мелодиці блюзу. Але в рамках джазової мелодики, зазвичай, відбувається синтез визначеного міжступеневого тяжіння та вертикального або гармонічного мислення, на якому базується мелодика джазової музики. Окрім вищезазначених характеристик, для мелодики джазової музики, при використанні внутрішньо ладових альтерацій, $є$ характерним застосування блюзових звукових тонів.

Окрім мелодики, вплив блюзу розповсюджується також і на принципи гармонічної організації джазової музики. Але необхідно зазначити, що визначений вплив має глибший характер. Принципи гармонічної організації джазу походять від західно-європейської музики. Подібний факт визначає і Ю. Чугунов в роботі «Гармония в джазе» (Чугунов, 1988, с. 5). Д. Вейсмен вказує, що в джазі використовуються і «деякі гармонічні елементи регтайму», які, як відомо, також базуються на принципах західно-європейської музичної традиції (Weissman, 2005). Але при розгляді визначеного питання необхідно також брати до уваги «неєвропейське» походження мелодики та гармонії одного з витоків джазової музики, тобто блюзу. В. Конен пов'язує своєрідність джазової гармонії 3 принципами «неакадемічного» блюзового інтонування (Конен, 1994, с. 79-80). Зазначене явище самобутнього інтонування, насамперед, стосується мелодики блюзу або його виконавських прийомів, але, в той же час, цей процес має відношення і до особливостей гармонічної функціональності. Як відомо, феномен домінантового тяжіння або домінантовості в блюзі має своєрідний та оригінальний характер. Подібної самобутності явище домінантовості в блюзовій музиці набуває завдяки тому, що мелодики опирається на блюзові звукові тони, що, насамперед, відроджує специфічне інтонування. Щодо визначення домінантовості в джазі, то необхідно зазначити, що вона знаходиться на межі між блюзом та західноєвропейською класичною традицією. Враховуючи той факт, що, не зважаючи на принципи побудови мелодичного матеріалу в традиційному джазі на акордову звукову структуру, практично всі внутрішньо ладові альтерації мелодики відбуваються за участю блюзових тонів, цілком зрозуміло, що прояв домінантовості набуває впливу також і від блюзової 
музики. Явище домінантового тяжіння, яке спирається, насамперед, на ладову ввіднотоновість є не настільки яскраво вираженим в джазовій музиці, як в західноєвропейській музичній традиціях, та за своїми стильовими ознаками також відповідає і блюзу. Необхідно зазначити, що в процесі розвитку, в межах джазової музики ступінь прояву вищезазначеного явища поступово зменшувалася, та ознаки, що притаманні західноєвропейській гармонічній системі набували більшого значення. Однак ми безперечно можемо зазначити, що вищевказаний вплив блюзу на джазову гармонію полягає головним чином в прояві явища домінантовості.

У той же час, принципи гармонічної організації блюзу найяскравіше знайшли відгук в музичному стилі boogie-woogie, характерна гармонічна структура якого повністю $\epsilon$ відображенням гармонічної послідовності архаїчного або класичного 12-ти тактового блюзового квадрату. Про абсолютну спорідненість boogie-woogie та блюзу пише і Д. Коллієр в роботі «Становление джаза», навіть визначаючи boogie-woogie, як «фортепіанний блюзовий стиль» (Коллиер, 1987, с. 258). Подібне до нього є визначення boogie-woogie в роботі Р. Кроуфорда та Л. Хамберліна «An Introduction to America's Music», де автори також відносять зазначений стиль до стильового відгалуження блюзової музики (Crawford, Hamberlin, 2013, с. 582). Важливим $\epsilon$ той факт, що серед творів, які написані в стилі boogiewoogie практично не існує прикладів відходу від гармонічної структури 12-ти тактового блюзового квадрату, що ще раз вказує на глибинну спорідненість цих двох музичних явищ неакадемічної музики ХХ ст. У монографії «The Story Of Boogie Woogie. A Left Hand Like God» П. Сілвестер зазначає походження музичного стилю boogie-woogie від блюзу наступним чином: «Boogie-woogie поступово став визнаватися як окрема фортепіанна форма, що набула розвитку від блюзового акомпанементу ${ }^{10}$ до сольного виконання» (Silvester, 2009, c. 5). Під час проведення аналізу характерних патернів, що використовуються в акомпанементі музичного стилю boogie-woogie, виявлястья їх безперечне базування на діатоніці блюзової мелодики. Також, до складу арсеналу виконавських прийомів музичного стилю boogie-woogie увійшов найхарактерніший прийом блюзової виконавської техніки, що в теорії джазової музики визначається як slide. Вищезазначений прийом первинно походить від відповідного виконавського прийому гітарної техніки. Завдяки використанню цього прийому, звукове забарвлення творів музичного стилю boogie-woogie набуває блюзового колориту, тому що саме завдяки йому можливе вірне відтворення звучання блюзових тонів, які відіграють основоположну роль в створенні блюзового саунду.

Крім того, відбиток блюзових характеристик, безумовно, простежується і в спектрі виконавських прийомів, що застосовуються в межах джазової музики. Насамперед, це стосується широкого застосування прийомів звукової артикуляції на духових інструментах, які є однією з головних характеристик джазової музики, що походить від виразності вокалу в блюзовій музиці (Weissman, 2005). До подібних прийомів інструментального виконавства належать прийоми growling, bend, slide, тріль тощо. До цієї ж категорії належить i використання в джазовому виконавстві неточного інтонування. Зазначене явище, насамперед, властиве для ступенів, що належать до категорії «плаваючих» в рамках блюзової діатоніки. Необхідно зауважити, що виділений аспект стосується не тільки вокального, а й інструментального виконавства. Однак, зрозуміло, що можливості темперованих інструментів в даному випадку є обмеженими. Тому, в цьому випадку, велике значення має внутрішнє слухове уявлення виконавця, яке повинно вірно відтворювати ладові альтерації, що є характерними для джазової музики.

Звертаючись до питання прояву в джазовій музиці характерних ознак блюзу як музичної форми, насамперед, необхідно вказати, що за визначенням дослідників джазової музики, саме музична форма 12-ти тактового блюзового квадрату $є$ «... найчастішою формою, що застосовується в джазовому репертуарі» (Hellmer, Lawn, 1996, с. 182). Про це

10 Як відомо, первинно блюзовий акомпанемент виконувався на гітарі. Автор визначає фортепіанний акомпанемент до блюзу, як похідний від гітарного та пише, що «акомпанемент фортепіано до блюзового співу був точною копією гітарної техніки» (Hellmer, Lawn, 1996, с. 5). 
пише і П. Таунсенд, зауважуючи, що джазові музиканти вважають блюз «одним з головних тестів» на джазову обізнаність та музичність (Townsend, 2000, с. 11). Ми, насамперед, можемо зауважити, що форма 12-ти тактового блюзового квадрату $\epsilon$ повноправною складовою арсеналу формоутворюючих засобів джазової музики. Але необхідно також відмітити той факт, що в рамках джазової музики гармонічна структура вищезазначеної форми зазнала певного розвитку та змін. Це стосується і додавання до акордового складу блюзового квадрату гармонічного звороту II-V ступенів, що $\epsilon$ характерним для гармонії джазової музики. Крім того, саме 3 джазовою музикою пов'язана поява нового різновиду блюзової форми, що в теорії джазової музики визначається як сучасний блюзовий квадрат, який знаменував еволюцію в принципах гармонічної організації джазу, що призвело до появи великої кількості нових різновидів музичної форми блюзового квадрату в контексті джазової музики. Серед них: мінорний блюзовий квадрат, блюзовий квадрат з бріджем, блюзовий квадрат у 3-х долевому метричному викладенні та ін. П. Таунсенд в роботі «Jazz in American Culture», підкреслюючи значимість зазначеної музичної форми для джазової музики вказує, що в джазовому напрямку не існує стилю, в якому б блюз «не займав важливу позицію» (Townsend, 2000, с. 11). Незважаючи на те, що в джазовій музиці стандартна форма 12-ти тактового блюзового квадрату зазнала чималих змін та трансформацій, в будь-якому своєму різновиді та із внесенням до неї будь-яких елементів, вона залишається феноменом блюзового формоутворення в рамках джазової музики. Крім того, перед нами постає вся глибина вищезазначеної музичної форми, в якій закладений потенціал до нескінченної кількості трансформацій та внесення новаторських рис, які походять, зокрема, від джазової музики.

Наукова новизна. У проведеному дослідженні вперше в українському мистецтвознавстві відбулося вивчення прояву характерних рис блюзу в рамках джазової музики.

Висновки. Спираючись на проведене дослідження ми можемо дійти до наступних висновків:

- найбільше відображення характерних ознак блюзу як музичного жанру в контексті джазової музики спостерігається в рамках музичного стилю bebop;

- ознаки маргінальності, що первинно походять від блюзу мали стратегічне значення в контексті розвитку джазової музики;

- вплив блюзу як музичної форми та музичного стилю прослідковується в музичному стилі джазової музики boogie-woogie;

- прояв стилістичних ознак блюзу, що визначаються як принципи гармонічної організації музичного матеріалу, в джазі знаходяться в сфері феномену домінантового тяжіння;

- вплив блюзу на джазову музику як музичного стилю в сфері мелодики полягає в тому, що принципів побудови мелодичного матеріалу джазу спираються на блюзову діатоніку, а також у прояві пентатонічного міжступеневого тяжіння;

- у рамках джазової музики отримали широке розповсюдження виконавські прийоми, які притаманні блюзу;

- у джазовій музиці музична форма 12-ти тактого блюзового квадрату набула нових рис та нових різновидів, залишаючись одночасно проявом ознак блюзового формоутворення в рамках визначеного музичного напрямку.

Таким чином, ми можемо зазначити, що вплив блюзу на джазову музику відбувається в сфері музичної форми, музичного стилю та музичного жанру, що дає нам право стверджувати про те, що блюз дійсно відіграє велику роль у процесі розвитку та становлення джазової музики.

\section{Список використаних джерел}

1. Амирханова С. А. Джаз как искусство самовыражения. Уфа : РИС УГАИ им. 3. Исмагилова, 2014. 193 с. 
ISSN 2410-1176 (Print) Вісник КНУКіМ. Серія Мистецтвознавство. Вип. 39. ISSN 2616-4183 (Online)

2. Бобер Ж. Культурная маргинальность и ее место в развитии культуры. Вестник Ленинградского государственного университета им. А.С. Пушкина. Санкт-Петербург, 2010. T. 2, № 4. C. 136-143.

3. Коллиер Д. Л. Луи Армстронг. Американский гений / пер. 3 англ. А. Денисов, М. Рудковская. Москва : Радуга, 1987. 424 с.

4. Коллиер Д. Л. Становление джаза. / пер. 3 англ. О. Медведев. Москва : Радуга, 1984. $392 \mathrm{c}$.

5. Конен В. Д. Третий пласт. Новые массовые жанры в музыке ХХ века. Москва : Музыка, 1994. 160 с.

6. Коровина Е. М. Происхождение американского блюза как проблема культурологического понимания : автореф. дис. канд. культурологии / Уральский государственный университет им. А. М. Горького. Екатеринбург, 2005. 28 с.

7. Леурда О. П. Технические и исторические аспекты мелизмов в массовой музыке ХХ века. Культурная жизнь Юга России, 2017. № 1 (64). С. 112-115.

8. Назин А. С. Особенности взаимодействия музыкального языка джаза и рок-музыки в XX - начале XXI веков. Terra Humana. Санкт-Петербург, 2014. № 2. С. 132-136.

9. Сыров В.Н. Стилевые метаморфозы рока или путь к третьей музыке. Нижний Новгород : Изд-во Нижегородского университета, 1997. 209 с.

10. Чугунов Ю. Н. Гармония в джазе. Москва : Советский композитор, 1988. - 153 с.

11. Шевченко А. С. Специфіка вокально-джазової культури виконавців. Актуальні питання мистеиької освіти та виховання. Суми, 2017. № 2 (10). С. 175-183.

12. Berendt, J. The Jazz Book. From Ragtime to The 21st Century / J. Berendt, G. Huesman. USA : Lawrence Hill Books, 2009. 816 p.

13. Crawford R., Hamberlin L. An Introduction to America's Music, New York : W. W. Norton \& Company, 2013. 624 p.

14. Hellmer J., Lawn R. Jazz Theory and Practice: For Performers, Arrangers and Composers. USA : Alfred Music, 1996. 312 p.

15. Silvester P. The Story Of Boogie Woogie. A Left Hand Like God. USA : Scarecrow Press, 2009. $438 \mathrm{p}$.

16. Townsend P. Jazz in American Culture. USA : Univ. Press of Mississippi, 2000. URL: https://books.google.com.ua/books?id=dUw7H5WVuJQC\&printsec=f rontcover \&dq=free+jazz+literature $\& h \mathrm{~h}=\mathrm{ru} \& \mathrm{sa}=\mathrm{X} \& \mathrm{ved}=0 \mathrm{ahUKEwj} 16 \mathrm{emThLDeAhUClYsKHaoqD}$ pMQuwUIdTAJ\#v=onepage \&q=blues\&f=false/2018-10-13 (Accessed: 13.10.2018).

17. Weissman D. Blues: The Basics. New York : Routledge, 2005. URL: https://books.google.com.ua/books?id=yYtR20TlGOoC\&printsec=frontcover\&hl=ru\&source=gbs_ ge_summary_r\&cad=0\#v=onepage \&q\&f=false/2018-10-3 (Accessed: 3.10 .2018 ).

\section{References}

1. Amirkhanova, S. (2014). Dzhaz kak iskusstvo samovyrazheniya [Jazz as an Art of Selfexpression]. Ufa: Ufimskii gosudarstvennyi institut iskusstv im. Zagira Ismagilova [Ufa State Institute of Arts named after Zagir Ismagilov].

2. Berendt, J., Huesman, G. (2009). The Jazz Book. From Ragtime to the $21^{\text {st }}$ Century. USA: Lawrence Hill Books.

3. Bober, Zh. (2010). 'Kul'turnaya marginal'nost' i ee mesto v razvitii kul'tury' [Cultural marginality and its place in the development of culture]. Vestnik Leningradskogo gosudarstvennogo universiteta im. A.S. Pushkina [Bulletin of Pushkin Leningrad State University]. T. 2, no. 4, pp. 136-143. kompozitor.

4. Chugunov, Yu. (1988). Garmoniya $v$ dzhaze [Harmony in Jazz]. Moscow: Sovetskii

5. Crawford, R., Hamberlin, L. (2013). An Introduction to America's Music, New York: W. W. Norton \& Company.

6. Hellmer, J., Lawn, R. (1996). Jazz Theory and Practice: For Performers, Arrangers and Composers. USA: Alfred Music. 
7. Kollier, D. (1987) Lui Armstrong. Amerikanskii genii [Louis Armstrong. American genius]. Translated from English by A. Denisov, M. Rudkovskaya. Moscow: Raduga.

8. Kollier, D. (1984). Stanovlenie dzhaza [Formation of jazz]. Translated from English by A. Medvedev. Moscow: Raduga.

9. Konen, V. (1994). Tretii plast. Novye massovye zhanry v muzyke XX veka [The Third Layer. New Mass Genres in the Music of the XX Century]. Moscow: Muzyka.

10. Korovina, E. (2005). Proiskhozhdenie amerikanskogo blyuza kak problema kul'turologicheskogo ponimaniya [The origin of American blues as a problem of cultural understanding]. Ural'skii gosudarstvennyi universitet im. A. M. Gor'kogo.

11. Leurda, O. (2017) Tekhnicheskie i istoricheskie aspekty melizmov v massovoi muzyke XX veka [Technical and historical aspects of melisms in the mass music of the XX century]. Kul'turnaya zhizn' Yuga Rossi,i no. 1(64), pp. 112-115.

12. Nazin, A. (2014) Osobennosti vzaimodeistviya muzykal'nogo yazyka dzhaza i rokmuzyki v XX - nachale XXI vekov [Features of interaction between the musical language of jazz and rock music in the $20^{\text {th }}$ - early $21^{\text {st }}$ centuries]. Terra Humana, no. 2, pp. 132-136.

13. Shevchenko, A. (2017) Spetsyfika vokalno-dzhazovoi kultury vykonavtsiv [Specificity of vocal-jazz culture of performers]. Aktualni pytannia mystetskoi osvity ta vykhovannia, no. 2 (10), pp. 175-183.

14. Silvester, P. (2009). The Story Of Boogie Woogie. A Left Hand Like God. USA: Scarecrow Press.

15. Syrov, V. (1997). Stilevye metamorfozy roka ili put' $k$ tret'ei muzyke [Style Metamorphoses of Rock or the Way to the Third Music]. Nizhnii Novgorod: izdatel'stvo Nizhegorodskogo universiteta.

16. Townsend P. (2000). Jazz in American Culture. USA: Univ. Press of Mississippi. Available at: <https://books.google.com.ua/books?id=dUw7H5WVuJQC $\&$ printsec $=$ frontcover $\& d q=$ free + jazz+literature $\& h l=r u \& s a=X \& v e d=0 a h U K E w j 16 e m T h L D e A h U C l$ YsKHaoqDpMQuwUIdTAJ\#v=onepage \&q=blues\&f=false/2018-10-13> [Accessed 13 Oct. 2018].

17. Weissman D. (2005). Blues: The Basics. New York: Routledge. Available at: $<$ https://books.google.com.ua/books?id=yYtR20TlGOoC\&printsec=frontcover\& $\mathrm{hl}=\mathrm{ru} \&$ source=gbs_ge_summary_r\&cad=0\#v=onepage \&q\&f=false/2018-10-3> [Accessed 3 Oct. 2018].

(С) Журба Я. О., 2018

Стаття надійшла до редакиії 25.09.2018 